\title{
The chiastic inversion in the argument of Romans 2:1-3:9 and the identity of the interlocutor in Romans 2:17-29
}

Authors:
Sang-Hoon Kim ${ }^{1}$
Kyu S. Kim
Affiliations:
'Department of Theology,
Chongshin University,
Republic of Korea
2Department of Theology,
Asia United Theological
University, Republic of Korea
Corresponding author:
Kyu Kim,
johnstott77@gmail.com
Dates:
Received: 08 July 2017
Accepted: 07 June 2018
Published: 09 Oct. 2018
mobile device
to read online.
How to cite this article:
Kim, S-H. \& Kim, K.S., 2018,
'The chiastic inversion in the
argument of Romans 2:1-3:9
and the identity of the
interlocutor in Romans
2:17-29', Verbum et Ecclesia
39(1), a1782. https://doi.
org/10.4102/ve.v39i1.1782
Copyright:
@ 2018. The Authors.
Licensee: AOSIS. This work
is licensed under the
Creative Commons
Attribution License.

This article intends to understand the identity of the interlocutor in Romans 2:17-29 by analysing Paul's argument design of Romans 2:1-3:9. Specifically, this work will focus on the identity of the interlocutor in Romans 2:17-29. This study detects Paul's elaborate chiastic structure in Romans 2:1-3:9, and we argue that the identity of the interlocutor should be considered in this structural context. Through our structural analysis, we will more clearly understand the intention of the author regarding the interlocutor. Contrary to the view of Thorsteinsson and Thiessen, it can be inferred that the identity of the interlocutor is not the Jewish proselytes but the Jews on the basis of our structural analysis. In Romans 2:17-29, the identity of the people of God is redefined in terms of the transformation of mind (i.e. the circumcision of the heart), and the discussions on the historical context of the transformation of the mind.

Intradisciplinary and/or interdisciplinary implications: This work challenges the previous understanding of the structural design of the Pauline texts, adding fresh insights on the identity of the interlocutor in Romans 2:17-29. It is expected that studies on the authorial design and its semantic implications are further developed through this work.

\section{Introduction}

This article intends to understand the identity of the interlocutor in Romans 2:17-29 by analysing Paul's argument design of Romans 2:1-3:9. Specifically, this work will focus on the identity of the interlocutor in Romans 2:17-29, and through structural analyses, we will more clearly understand the intention of the author regarding the interlocutor. Traditionally, the interlocutor in Romans 2:17 is considered as a 'pretentious' Jew (e.g. Stowers 1981:113; Tobin 2014:115; Windsor 2014:191-192), and it was believed that, in Romans 2:28-29, Paul redefines Jewishness according to the circumcision of the mind (e.g. Barclay 1998:536-556; Campbell 2009:565; Dunn 1988:109). However, a challenging view is emerging in current New Testament scholarship (e.g. Thiessen 2014:373-391; Thorsteinsson 2003). We will briefly summarise their interpretations as follows.

\section{A challenging view}

In his influential monograph, Thorsteinsson contends that the interlocutor in Romans 2:17 is not a Jew but someone who wants to be called a Jew (2003:199). He notes that, in 1 Corinthians

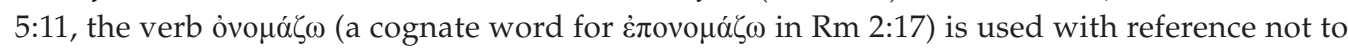
a real brother but to the one who calls himself a brother. In this perspective, Thorsteinsson

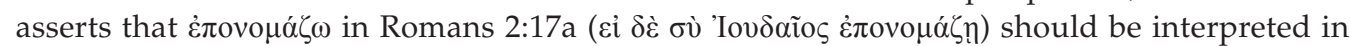

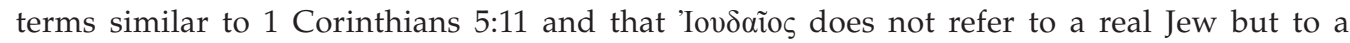
proselyte. Thiessen also recently argues that 'Iovסaios in Romans 2:17 is not a real Jew but a Gentile proselyte interlocutor. In Romans 3:1-9, Paul discusses the benefits of physical circumcision. For that reason, Thiessen (2014:381) maintains that we should not conclude that Paul denies physical circumcision and redefines Jewishness in Romans 2:28-29. Thiessen notes that Jews sometimes mention theft and adultery in the list of sins (Rm 2:21-22) as Gentile sins (e.g. Wisdom of Solomon, ch. 14:24-28). Furthermore, Thiessen (2014:387) points out that the circumcision performed on the eighth day after birth is valid and contains a covenantal advantage. Ishmael was circumcised at the age of 13 but '[Ishmael] falls outside the covenant God made with Abraham. His circumcision has no covenantal or legal benefit'. Therefore, Thiessen holds that, if a Gentile seeks to become a Jew through his circumcision, his pursuit would turn out to fail, as his circumcision is not performed on the eighth day after his birth 
and it infringes on the Jewish cultic law. ${ }^{1}$ Accordingly, the Gentile proselytes' circumcision cannot please God (cf. Rm 2:29). Thus, Thiessen (2014:309) concludes that the Jew

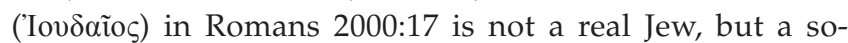
called Jew, and that the interlocutor is simply the one who believes himself to be a Jew.

In order to understand the identity of the interlocutor in Romans 2:17-29, we need to consider the following questions. What does Paul mean by the benefits of the circumcision in Romans 3:2? If Paul denies the value of the physical circumcision, why does Paul state the advantage

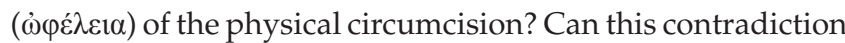
be resolved? How, then, can we interpret Romans 2:28-29? Does Paul repudiate the physical circumcision (Thiessen 2014:384)? Despite the ongoing scholarly discussions, these questions remain unresolved.

Although Paul's logic concerning this issue is inevitably related to the argument design of Romans 2:17-3:9, there have been few detailed studies on Paul's argument design and structure in Romans 2:17-3:9. Moreover, Thorsteinsson and Thiessen are not interested in structural analysis. Therefore, in this article, we intend to make clear the flow of Romans 2:17-3:9 which is yet to be clarified in terms of an authorial stylistic view. ${ }^{2}$ In particular, we will identify the chiastic structure of Romans 2:17-3:9 which has not been detected by previous interpreters, as far as we know. Thus, we will examine Paul's intention and the position of Judaism in Romans 2:1-3:9 by analysing the stylistic features including parallelistic and chiastic structures. ${ }^{3}$ This work begins with the specific analysis of Paul's elaborate chiastic inversion in Romans 2:1-3:9, as follows.

\section{Paul's argument design of Romans 2:1-3:9}

In this section, we will explore the literary context of Romans 2:1-3:9, particularly Paul's argument design. Before considering Romans 2:1-3:9, we should consider the wider literary context of the given text. It should be noted that Romans 1:18-3:18 frames one group of clusters, which deals with the issue of human sins. To put it simply, the overall structure can be organised as set out in Figure 1.

Firstly, the sinful reality of human beings is elucidated and listed in Romans 1:18-32 (A) and Romans 3:10-18 (A'). Secondly, both Romans 2:1-16 (B) and Romans 3:1-9 (B')

1.Contrary to the Masoretic Text, the translator of the Septuagint describes all nations as circumcised in LXX Jeremiah 9:24-25, and in the subsequent verses, 'they [i.e. all nations] are uncircumcised in their flesh'. Thiessen, 'Paul's Argument against Gentile Circumcision', 389. Thiessen interprets that this is related to the Jewish cultic regulations which consider the circumcision performed not on the eighth day after birth to be invalid.

2.Most interpreters divide Romans 2:1 and Romans 2:12-16. Exceptions are found in Witherington 2004:127.

3.The stylistic approach has drawn little attention in New Testament scholarship. On the contrary, the linguistic approach has been attempted by several scholars. More attempts for stylistic analysis have been made in Old Testament scholarship. For instance, see Dorsey (1999) and Walsh (2001). In addition, for exceptional examples instance, see Dorsey (1999) and Walsh (2001). In addition, for exceptional examples
of the investigation into literary/stylistic design concerning the New Testament, see Welch (1981), Bauer (1988), Thomson (1995), Brouwer (2000) and Kim (2014).
Wel

\begin{tabular}{|c|c|c|c|c|}
\hline \multirow[t]{4}{*}{ A } & \multicolumn{3}{|c|}{ Romans 1:18-32 (Unjust people) } & \multirow{2}{*}{$\begin{array}{l}\text { Gentiles } \\
\text { Gentiles - Jews }\end{array}$} \\
\hline & \multirow[t]{2}{*}{ B } & \multicolumn{2}{|r|}{$\begin{array}{l}\text { Romans 2:1-16 (God's judgement and } \\
\text { reward) }\end{array}$} & \\
\hline & & $x$ & $\begin{array}{l}\text { Romans 2:17-29 (The Jews, the law- } \\
\text { breakers) }\end{array}$ & Jews \\
\hline & $\mathrm{B}^{\prime}$ & & $\begin{array}{l}\text { hans 3:1-9 (God's judgement to the } \\
\text { ust) }\end{array}$ & Jews - Gentiles \\
\hline$A^{\prime}$ & \multicolumn{3}{|c|}{ Romans 3:10-18 (None righteous) } & Both \\
\hline
\end{tabular}

FIGURE 1: The structure of Romans 1:18-3:18

deal with divine judgement. In the centre of the chiasm, Romans 2:17-29 (X) points out that the so-called Jews do not observe the law. Thirdly, the focus of Paul's critique is given to the Gentiles ( $\mathrm{Rm} \mathrm{1:18-32).} \mathrm{The} \mathrm{focus} \mathrm{is} \mathrm{transited} \mathrm{from} \mathrm{the}$ Gentiles to the Jews in Romans 2:1-16, and the so-called Jews are critiqued by Paul in Romans 2:17-29. Again, the focus is transited from the Jews to the Gentiles in Romans 3:1-9, and in Romans 3:10-18 the sinful reality encompasses everybody. This chiastic structure is symmetrical, and in this chiasm, it is likely that the so-called Jew in Romans 2:17 as a fictive interlocutor refers to an ethnic Jew, not to a Gentile proselyte. In the following sections, we will more specifically discuss the chiastic structures in the sub-units in Romans 2:1-3:9 and will consider its implications for the identity of the interlocutor.

\section{Romans 2:1-16}

Romans 2:1-16 forms a chiastic structure (A-X-A'): vv. 1-5 (A), vv. 6-11 (X) and vv. 12-16 (A'). In this chiasm, A and $A^{\prime}$ are paired up, and $X$ is located in the centre between them. The concept of divine judgement is prominent in $A-A^{\prime}$ : A discusses the unavoidable judgement, and $\mathrm{A}^{\prime}$ is concerned with the judgement upon the sinners. The concept of the judgement repeatedly appears in Romans 2:1-5 and Romans

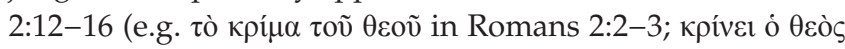
in Romans 2:16 and its cognate words). On the contrary, these words are not used in Romans 2:6-11, which deals with God's impartiality in his reward and retribution.

Specifically, Romans 2:1-16 comprises the chiasm as shown in Figure 2: A (Rm 2:1-5) - X (Rm 2:6-11) - A' (Rm 2:12-16). ${ }^{4}$ A (vv. 1-5) offers an elucidation concerning judgement and deeds, which involves the discussion of God's goodness. In the centre of the chiasm, X (Rm 2:6-11) again highlights the theme of judgement and deeds. A' (vv. 12-16) elaborates the theme regarding judgement and deeds according to the law. $\mathrm{A}-\mathrm{A}^{\prime}$ are in parallel in terms of

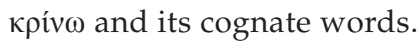

A ( $\operatorname{Rm} 2: 1-5)$ can be seen as one unit: there is a parallelism in Romans $2: 1-5\left(a b-a^{\prime} b^{\prime}\right)$, and a thematic shift is found in the divine judgement upon those who judge in Romans 2:1-5 and to God's impartial compensation and judgement in

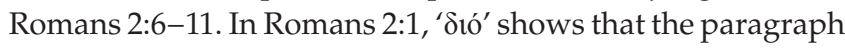
4.Paul's use of diatribe in this unit has been widely noticed by scholars, for example, Witherington (2004:75), Stowers (1981:93) and Dunn (1988:78-79). 


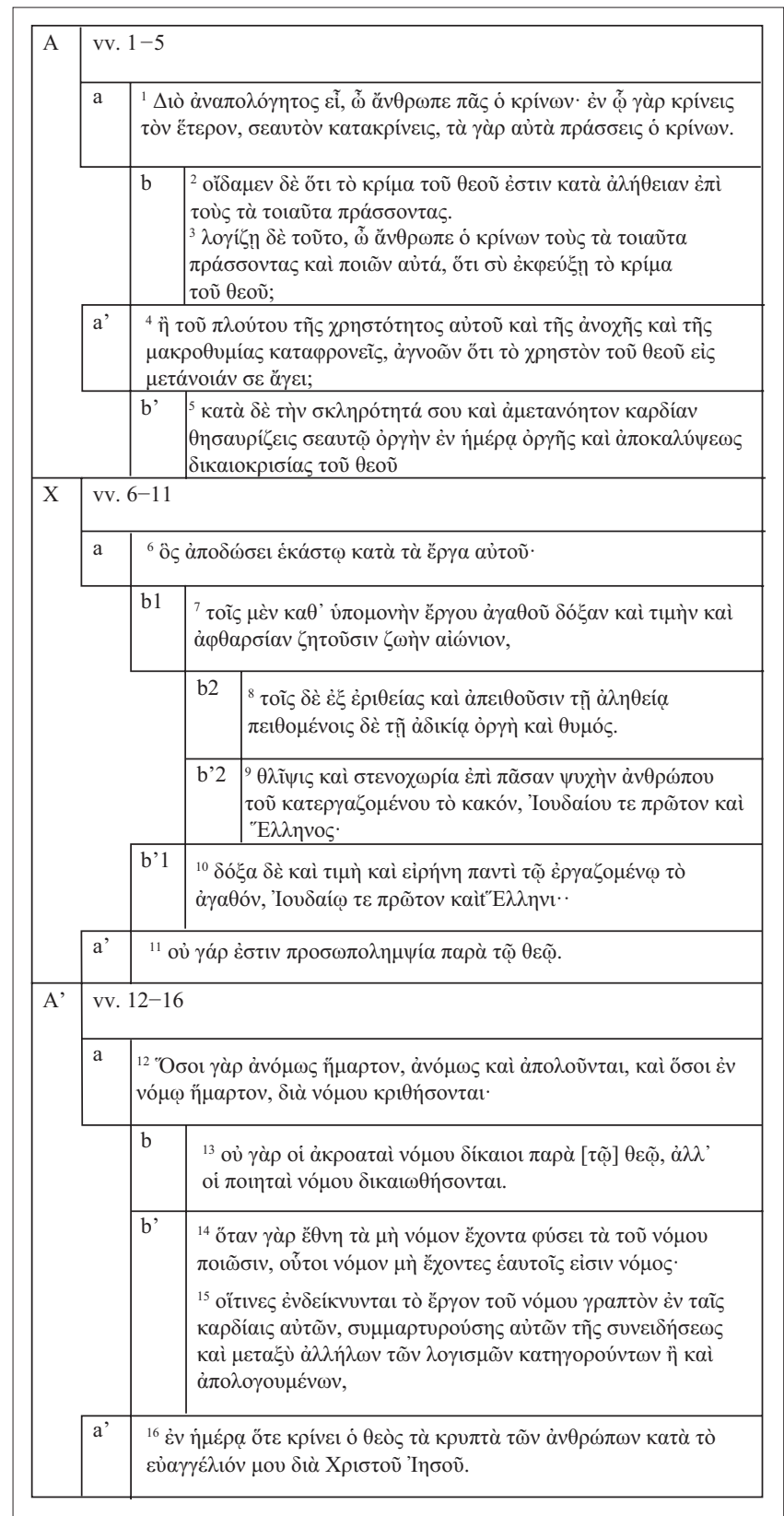

FIGURE 2: The chiastic structure of Romans 2:1-16.

in Romans 2:1-16 could be 'a continuation of, or based on' Romans 1:18-32 (Witherington 2004:73) but also may be read as a logical corollary from Romans 1:18-19, which mentions God's wrath. Each sub-unit in Romans 2:1-16 also has inner cohesiveness.

A (Rm 2:1-5) is justified as follows - Romans 2:1-5 consists of a smaller parallelism: a (Rm 2:1) - b (Rm 2:2-3) - a' (Rm $2: 4)-b^{\prime}(\operatorname{Rm} 2: 5)$, which reiterates the theme of judgement. a ( $\mathrm{Rm}$ 2:1) is concerned with the person who judges another. ${ }^{5}$ The intensive fourfold uses of ' $\kappa \rho$ í $v \omega^{\prime}$ here establishes an embedded chiasm of a-b- $\mathrm{b}^{\prime}-\mathrm{a}$ in 2:1. ${ }^{6}$ And b (Rm 2:2-3)

5.For a specific discussion on the meaning of $\delta$ to, see Cranfield $(1975: 85)$.

6. Here a-a' is in parallel in terms of 'o $\kappa \rho i v \omega v$ ', and recapitulates what Paul intends to say, that is, the one who judges another does the same things with those who he or she judges. And $b-b$ ' begins with the conjunction 'ő $\tau$ ' and displays a chiastic phrasal

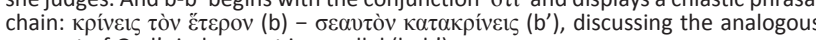
concept of God's judgement in parallel $\left(b-b^{\prime}\right)$. shows that there will be the judgement of God, comprising an inner, embedded chiasm (a, Rm 2:2a - b, Rm 2:2b - a', Rm 2:3a - b', Rm 2:3b). ${ }^{7}$ It seems that, in Romans 2:4 (a' of Rm 2:1-5), Paul intends a thematic shift to another theme: from the judgement to God's mercy. In a' (Rm 2:4), God's kindness (or mercy) and patience is delineated, and is contrasted with the judgement of human beings ( $a, \operatorname{Rm} 2: 1)$. a' ( $R m$ 2:4) is also justified by an inner, embedded chiasm $\left(a-b-b-b^{\prime}\right){ }^{8}$ In Romans 2:5 ( $\left.b^{\prime}\right)$, Paul reiterates the theme of divine judgement in parallel with $b(\operatorname{Rm~} 2: 2-3)$, but some variation from $b$ is also found (i.e. Paul supplements a theme of wrath).

$X(\mathrm{Rm} \mathrm{2:6-11)}$ is justified by an elaborate chiastic structure $\left(a-b 1-b 2-b^{\prime} 2-b^{\prime} 1-a^{\prime}\right)$, and Paul builds up the discussions on the judgement and reward. a-a' comprises 15 syllables, denoting a mathematically balanced inclusio. a-a' offers a general premise on God's personality: God will reward according to each one's deeds (a), and he is impartial ( $\left.a^{\prime}\right)$. Thus, the thematic thread flows as follows: the theme of God's impartial reward and retribution which begins in Romans 2:6 and ends in Romans 2:11, and the contrast between the doers of the law and the hearers of the law. Romans 2:7 (b1) is contrasted with Romans 2:8 (b2), ${ }^{9}$ and in a similar way, Romans 2:9 $\left(b^{\prime} 2\right)$ is set against Romans 2:10 (b'1). ${ }^{10}$ While Romans 2:7 (b1) and Romans 2:10 (b'1) delineate a positive concept (reward), Romans 2:8 (b2) and Romans 2:9 ( $\left.b^{\prime} 2\right)$ discuss a negative concept (retribution). b1-b'1 elucidates the theme of reward, and $b 2-b^{\prime} 2$ expounds the concept of divine judgement. ${ }^{11}$ So, in this sub-unit (Rm 2:6-11), God is impartial according to the deeds.

$\mathrm{A}^{\prime}$ (Rm 2:12-16) is a unit which consists of four constituents, a $(\operatorname{Rm~2:12)~-~b~}(\operatorname{Rm~2:13)~-~b'~(Rm~2:14-15)~-~a'~(Rm~2:16),~}$ creating a chiastic structure. Romans 2:12 (a) and Romans 2:16 (a') place their focus on the judgement. On the contrary, Romans 2:13 (b) and Romans 2:14-15 (b') draw attention to

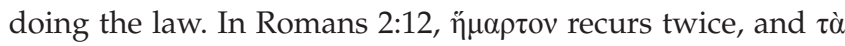

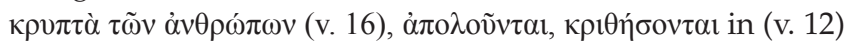

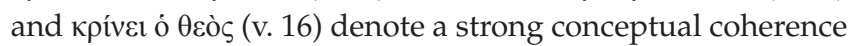
among these verses. In Romans 2:13 and 2:14-15, similar

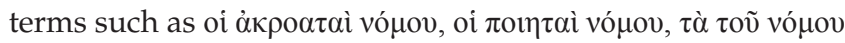

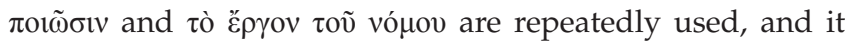
shows that $b(\operatorname{Rm} 2: 13)-b^{\prime}(\operatorname{Rm} 2: 14-15)$ are paralleled in a closer relationship. In this paragraph, the issue of the law is introduced for the first time.

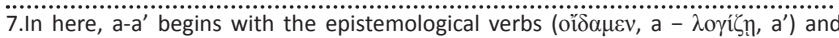
opens the discussions that there will be God's judgement in $b-b^{\prime}$.

8.In this embedded chiasm, a-a' describes God's personality centred on mercy

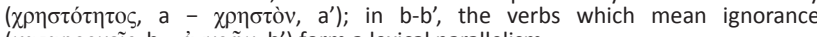

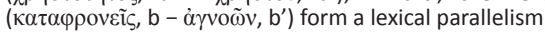

9.b1-b2 contains a grammatical, embedded parallelism ( $\left.a-b-a^{\prime}-b^{\prime}\right)$ and is contrasted

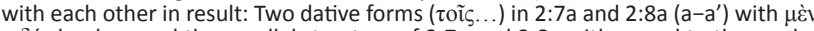
- $\delta \varepsilon$ c clearly reveal the parallel structure of 2:7a and 2:8a with regard to those who would receive divine reward and judgement, while $2: 7 b$ and $2: 8 b\left(b-b^{\prime}\right)$ delineate what will be given according to the deeds as divine reward and judgement.

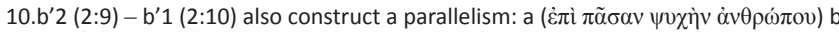

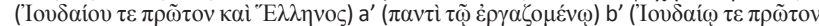
каì "E $\mathrm{\lambda} \lambda \eta v \mathrm{v})$.

11.It is found that there is a connection between b2 $(2: 8)-b^{\prime} 2(2: 9)$, constituting the

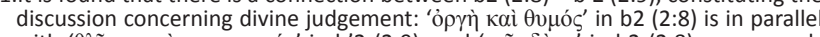

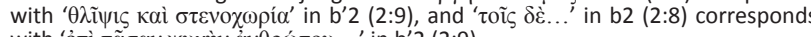
with 'ह் $\pi$ ì $\pi \tilde{\alpha} \sigma \alpha v \psi v \chi \eta े v ~ \dot{\alpha} v \theta \rho \omega ́ \pi 0 v . . . '$ in b'2 (2:9). 
As a whole, Romans 2:1-16 can be justified as one cluster. The concept of divine judgement is pivotal in Romans 2:1-16, and the main issue is transited to the transgression of the socalled Jews in Romans 2:17-29. The motif of the divine judgement is missing in Romans 2:17-29 and reappears in Romans 3. Accordingly, the demarcation of the paragraphs should be between Romans 2:16 and 2:17 in thematic terms.

\section{Romans 2:17-29}

This section will discuss Romans 2:17-29 in terms of its chiastic inversion.

Romans 2:17-29 sets out the chiastic structure of A (Rm 2:17-20) - B (Rm 2:21-23) - X (Rm 2:24) - B' (Rm 2:25-27) - A' ( $R m$ 2:28-29). A ( $R m$ 2:17-20) forms a1-a2-a3-X-a'1-a'2-a'3

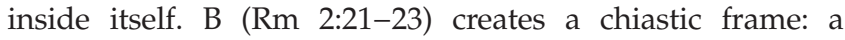
( $\operatorname{Rm} 2: 21 a)$ - b1 (Rm 2:21b) - b2 (Rm 2:22a) - b3 (Rm 2:22b) - a ( $\operatorname{Rm} 2: 23) . X(\operatorname{Rm~2:24)}$ is the centre of the chiastic structure, and serves as a linking point between $A-B(\operatorname{Rm} 2: 17-23)$ and $\mathrm{B}^{\prime}-\mathrm{A}^{\prime}$ (Rm 2:25-29). B' (Rm 2:25-27) holds a parallelism: a $(\operatorname{Rm} 2: 25 a)$ - b (Rm 2:25b) - a' (Rm 2:26) - b' (Rm 2:27). What was intended by Paul in Romans 2:17 and Romans 2:29, an inclusio, seems to be a re-definition of the true Jews. In Romans 2:28-29, Paul points out that the true Jews are defined in terms of the inwardly (or epistemological) criteria, and that the prerogatives of the physical Jew were ended. The focus of Romans 2:17-29 is posited on the point that the Jews claim their advantages. They are condemned for their disobedience to the law.

We justify Romans 2:17-29 as an independent unit. Firstly, there is a thematic shift in Romans 2:17: (1) the theme of divine judgement in Romans 2:1-16 is transited to the issue of the Jews (the sinfulness of the Jews is revealed in Romans 2:17-29, but the divine judgement is not explicitly referenced); (2) the motif of the Jews in Romans 2:17-29 is shared with Romans 3:1-2, but we should note that there is an inclusio between Romans 3:1-2 and Romans 3:9. The negative tone towards the Jews in Romans 2:17-29 is switched into a positive nuance in Romans 3:1-2. So, Romans 3:1-2 should be distinguished from Romans 2:29. Secondly, Romans 2:17-29 contains five sub-units and a chiastic structure is included in the paragraph: vv. 17-20 (A), vv. 21-23 (B), v. 24 $(\mathrm{X})$, vv. 25-27 (B'), vv. 28-29 (A'). Romans 2:17-20 (A) and

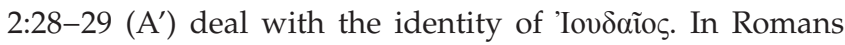
2:21-23 (B) and 2:25-27 ( $\left.\mathrm{B}^{\prime}\right)$, Paul points out that the so-called Jews do not observe the Torah. Romans 2:24, which delineates that God is blasphemed by the so-called Jews, is placed in the middle of the paragraph and divides Romans 2:21-23 and 2:25-27. Thirdly, in Romans 2:17-29, we identify the complex chiastic structure in Romans 2:17-29.

In A (Rm 2:17-20), Paul discusses the pride of the so-called Jews, and this sub-unit is divided into a complex chiastic composition as a1a2a3-x-a'1 $a^{\prime} 2 a^{\prime} 3$. Particularly, the knowledge in $a 2-a^{\prime} 2$ and the law in a3-a'3 repeat the conceptual stress of the pride on the law.
B (Rm 2:21-23) comprises five sentences, and while the first part (a, 2:21a) is an introductory opening, 2:23 ( $\left.\mathrm{a}^{\prime}\right)$ serves as a conclusive closing, thus creating an inclusio. Romans 2:21a is concerned with human beings and Romans 2:23 is about God. In Romans 2:21b-22, stealing (b1, v. 21b) is in parallel with robbing temples (b3, v. 22b), and adultery is located in the middle of them (b2, v. 22a). Adultery is a sin among human beings, but it could symbolically refer to idolatry. a-b1 (or including b2) is associated with human beings, and b3-a' is concerned with God. The pattern of similar sound, using a definite article (o) or a relative pronoun (òs) in the first place, also makes this sub-unit coherent, and in this sub-unit, Paul condemns the so-called Jews concerning their contradictory sins. While X (Rm 2:24), quoting Isaiah 52:4, complements Romans 2:21-23; it is distinguished from Romans 2:21-23 in terms of the pattern. Simultaneously, the contents of Romans 2:24 are connected to Romans 2:25. So, Romans 2:24 functions as a kind of hinge between Romans 2:21-23 and 2:25-27.

$\mathrm{B}^{\prime}$ (Rm 2:25-27) contrasts circumcision and transgressor of the law with uncircumcision and doer of the law respectively. This sub-unit contains a parallelism $\left(a b-a^{\prime} b^{\prime}\right)$, and the term

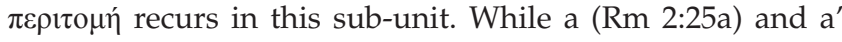

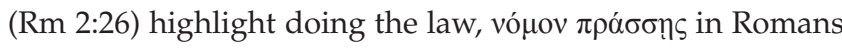

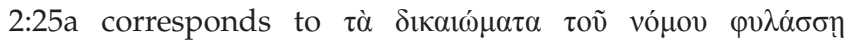
in Romans 2:26. On the other hand, $\pi \alpha \rho \alpha \beta \alpha$ tn

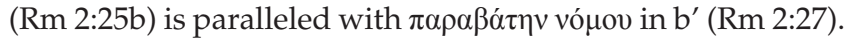

In addition, $A^{\prime}(\operatorname{Rm~2:28-29)~elucidates~who~is~the~true~Jew.~} \dot{o}$

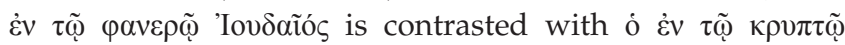

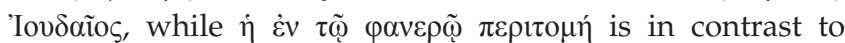

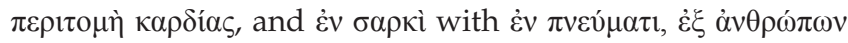

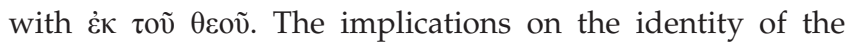
interlocutor relating to this aspect will be discussed in a following section.

\section{Romans 3:1-9}

In this sub-section, we will analyse the chiastic structure of Romans 3:1-9 (see Figure 4).

In Romans 3:1-9, Paul puts forth a complex chiasm: A (Rm 3:1-2) - B1 (Rm 3:3-4) - B2 (Rm 3:5-6) - B'1 (Rm 3:7) - B'2 $(\operatorname{Rm} 3: 8)-\mathrm{A}^{\prime}(\operatorname{Rm} 3: 9)$. A ( $\left.\operatorname{Rm} 3: 1-2\right)-\mathrm{A}^{\prime}(\operatorname{Rm} 3: 9)$ regards the advantages of the Jews. $A-A^{\prime}$ does not mention God, but the axis of $B 1-B 2-B^{\prime} 1-B^{\prime} 2$ pivots on contrasting God with

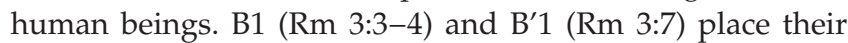
focus on the truth (or truthfulness) of God, 'Is God truthful (or faithful)?', while B2 (Rm 3:5-6) and B'2 (Rm 3:8) accentuate the righteousness of God, 'Is God righteous to judge?'

Romans 3:1 opens the unit of Romans 3:1-9 and serves as an inclusio with Romans 3:9a. Romans 3:1 and 3:9a offer the same content, while Romans 3:2 and 3:9b are contrasted in

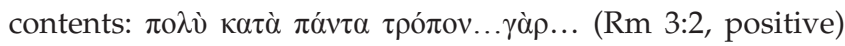

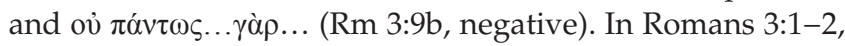
Paul admits that the Jew holds some advantages, but in Romans 3:9, Paul states that the Jews do not have advantages. Possibly, Romans 3:9 is Paul's conclusion. We should also 
note that there is a logical gap between Romans 3:1-2 and 3:3-4. Romans 3:1 is Paul's question and 3:2 is Paul's answer. Yet, in Romans 3:3, Paul does not elucidate the answer of Romans 3:2 but proceeds to its arguments towards the conclusion in Romans 3:9. That is, Romans 3:1-2 is not Paul's focus in Romans 3:1-9. Rather, it seems that Romans 3:1-2 are hinge verses connecting to the discussions on the Jews in Romans 2:17-29.

B1 ( $\mathrm{Rm} \mathrm{3:3-4)} \mathrm{contrasts} \mathrm{God} \mathrm{with} \mathrm{human} \mathrm{beings,} \mathrm{and} \mathrm{a}$ chiasm $\left(\mathrm{a}-\mathrm{x}-\mathrm{a}^{\prime}\right)$ is embedded inside. ${ }^{12}$ B2 ( $\mathrm{Rm}$ 3:5-6) develops Paul's idea through a triple chain link of $a-x-a^{\prime} \cdot{ }^{13}$ B'1 (Rm 3:7) and B'2 (Rm 3:8) are counterparts to B1 (Rm 3:3-4) and B2 (3:5-6), respectively. If so, we will specifically discuss the identity of the interlocutor on the basis of this structural analysis.

\section{The identity of the interlocutor}

As shown in the previous section 'Paul's argument design of Romans 2:1-3:9', we can justify our observation that Romans 2:1-3:9 consists of three clusters ( $\operatorname{Rm} 2: 1-16 ; 2: 17-29$; and 3:1-9). Firstly, Romans $2: 1-16$ is an enclosed unit. This unit denotes that the one who judges turns out to be the one who is judged, and that divine judgement will be certainly given to him. Secondly, we do not detect the concept of divine judgement in Romans 2:17-29. Romans 2:17-29 focuses on two questions: (1) Can the Jews boast? and (2) Who are the true people of God? Thirdly, in Romans 3:1-9, Paul returns to the concept of divine judgement, while the falsehood of human beings is contrasted with the truthfulness of God.

Fourthly, each of these three paragraphs contains its complete chiasm, and they constitute their own cohesive entity. For instance, Romans 2:1-3:9 has A-X-A' structure. The theme of divine judgement in $\mathrm{A}\left(\mathrm{Rm}\right.$ 2:1-17) recurs in $\mathrm{A}^{\prime}$ (Rm 3:1-19). On the contrary, the theme of divine judgement is not found in X (Rm 2:17-29), which delineates the true people of God. In A ( $\operatorname{Rm} 2: 1-17)$, the one who escapes the divine judgement is the law observer. In $X$, the question is given: Are the so-called Jews the law observers? If the so-called Jew does not observe the law, he or she is simply an outwardly Jew, not an inwardly Jew. In $\mathrm{A}^{\prime}$, the Jew has some benefits. However, all human beings are fundamentally sinful, and the Jews are equal with the non-Jews in terms of divine judgement ( $R m$ 2:6, 12).

Fifthly, in $\mathrm{A}-\mathrm{A}^{\prime}$, the Jews and the Gentiles alike will be under divine judgement and salvation, and the focus of $X$ is placed upon the Jews. Whereas the issue concerning the Jews is delineated in $\mathrm{A}-\mathrm{A}^{\prime}(\operatorname{Rm} 2: 12-13 ; 3: 1-2)$, the Gentiles are discussed along with the Jews.

That is to say, understanding Paul's argument design enables the readers to more clearly perceive the focus of the given text. The identity of the interlocutor in Romans 2:27 is inevitably

12.A rhetorial question is raised in a and answered in $a^{\prime}$, while $x$ is an emphatic,

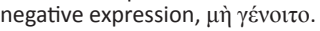

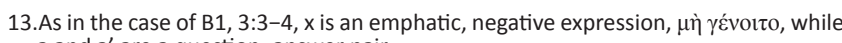
$a$ and $a^{\prime}$ are a question-answer pair. connected to that of the interlocutor in Romans 2:1-16. Researchers diverge on whose sins Paul is blaming in Romans 2:1-11, and their claims can be categorised in the following three perspectives: (1) Paul critiques the Jews; (2) Paul critiques the Gentiles; and (3) Paul principally critiques the Jews but also the Gentiles.

The scholars in support of the first option understand Romans 2:1-11 as Paul's criticism towards the Jews, and they argue that $\delta$ io in Romans 2:1 is not connected to the sins of the Gentiles in Romans 1:21-32, but to the wrath of God in Romans 1:18-19 (e.g. Moo 1996:129; Nygren 1967:115). The second group of scholars highlights the link between Romans 2:1-11 and the previous paragraph, and contends that Paul is condemning the sins of the Gentiles, not the Jews. Elliott (2014:168-223) writes that $\delta$ io in Romans 2:1 is an inferential conjunction to display the logical corollary from the preceding passage. Stowers (1981:110) also argues: 'The function of Romans 2:1-5 is to bring home, to concretize and to sharpen the indictment in Romans 1:18-32 (especially vv. 28-32) for Paul's audience'.

Lastly, some interpreters (e.g. Witherington 2004:76) take an eclectic viewpoint and read Romans 2:1-11 as Paul's criticism both to the Jews and the Gentiles who had a sense of ethical superiority. Bassler (1982:121-137) considers that Romans 2:1-11 is connected to Romans 1:16-32, and that Romans 2:11 is the thematic introduction of Romans 2:12-29. Dunn (1988:80) also thinks of Romans 2:1-11 as a hinge unit to link Romans 1:18-32 with Romans 2:12-3:8 in terms of God's impartiality.

We can trace the identity of the interlocutor in Romans 2:1 by understanding Paul's argument design, particularly the elaborate chiastic inversion in Romans 2:1-16, which is divided as A ( $\operatorname{Rm~2:1-5)~-~X~(Rm~2:6-11)~-~A'~(Rm~2:12-16).~}$ In the centre of the structure, $X(\operatorname{Rm} 2: 6-11)$ is concerned with both Jews and Greeks. In the parallel of A (Rm 2:1-5) - A' ( $\mathrm{Rm}$ 2:12-16), it is notable that the discussion about Jews is not delineated in $\mathrm{A}^{\prime}$ ( $\mathrm{Rm}$ 2:12-16). In addition, the interlocutor in Romans 2:1 is called 'all the people who judge'

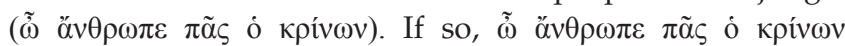
encompasses the Jews and the Gentiles.

Then, who is the interlocutor (the one who is called a Jew) in Romans 2:17? Is he a Jew or a Gentile proselyte who believes himself to be a Jew? We identify a chiasm in Romans 2:17-39 as follows: A (Rm 2:17-20) - B (Rm 2:21-23) - X (Rm 2:24) - B' ( $\operatorname{Rm} 2: 25-27)-\mathrm{A}^{\prime}(\operatorname{Rm} 2: 28-29)$, and the interlocutor should be considered in this structure. Romans 2:17 in A ( $R m$ 2:17-20) should be read in relation to $\mathrm{A}^{\prime}$ (Rm 2:28-29). Does Romans 2:28-29 refer to a Jew or a proselyte? In the context of Romans

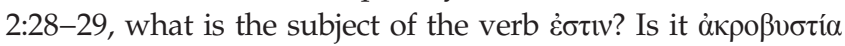
(i.e. Gentiles) who fulfilled the law in Romans 2:27? Yet, in terms of the structure, the connection between Romans 2:27 and 2:28 is not clear (see Figure 3). As Romans 2:27 belongs to $\mathrm{B}^{\prime}$ and Romans 2:28 is included in $\mathrm{A}^{\prime}$, 'Iovdaiós in Romans 2:28 should be considered in relation to the connection between $\mathrm{A}$ 


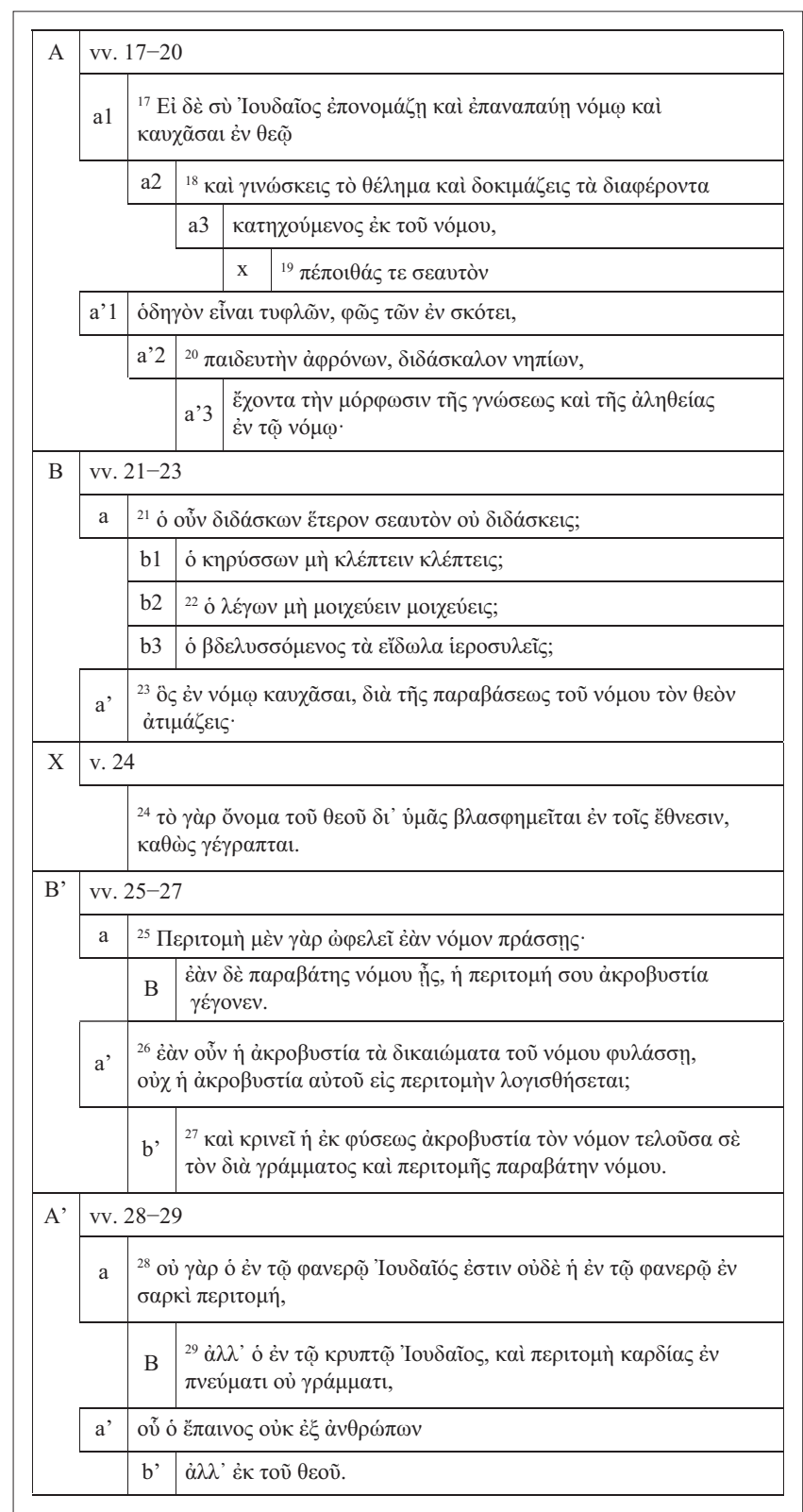

FIGURE 3: The chiastic inversion in Romans 2:17-29.

( $\operatorname{Rm} 2: 17-20)-\mathrm{A}^{\prime}(\operatorname{Rm} 2: 28-29)$. So, if we are aware that Romans 2:27 is not directly connected to Romans 2:28 in terms

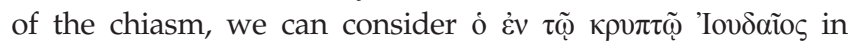
Romans 2:29 in the context of the discussion about the Jews ( $\operatorname{Rm} 2: 17-20)$, and not about the uncircumcised in Romans 2:27.

B (Rm 2:21-24) - B' (Rm 2:25-27) is bound up in terms of some common elements: Gentiles (Rm 2:24) and others (Rm 2:21)/the uncircumcised ( $R m$ 2:25-27); breaking the law ( $R m$

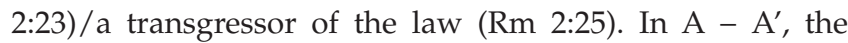
elements about the Gentiles are not expressed on the surface. Instead, A - $\mathrm{A}^{\prime}$ should be read in terms of the discussion about the Jews. Further, Paul's discussion in Romans 2:28-29 proceeds in Romans 3:1-2 with the inferential connective oṽv. Paul cites Isaiah 52:5 in X ( Rm 2:24, the centre of the chiastic structure), and this is also a critique towards the ethnic Jews. It is doubtful that the critique in Romans 2:24 is ascribed to merely the circumcised proselytes except for the

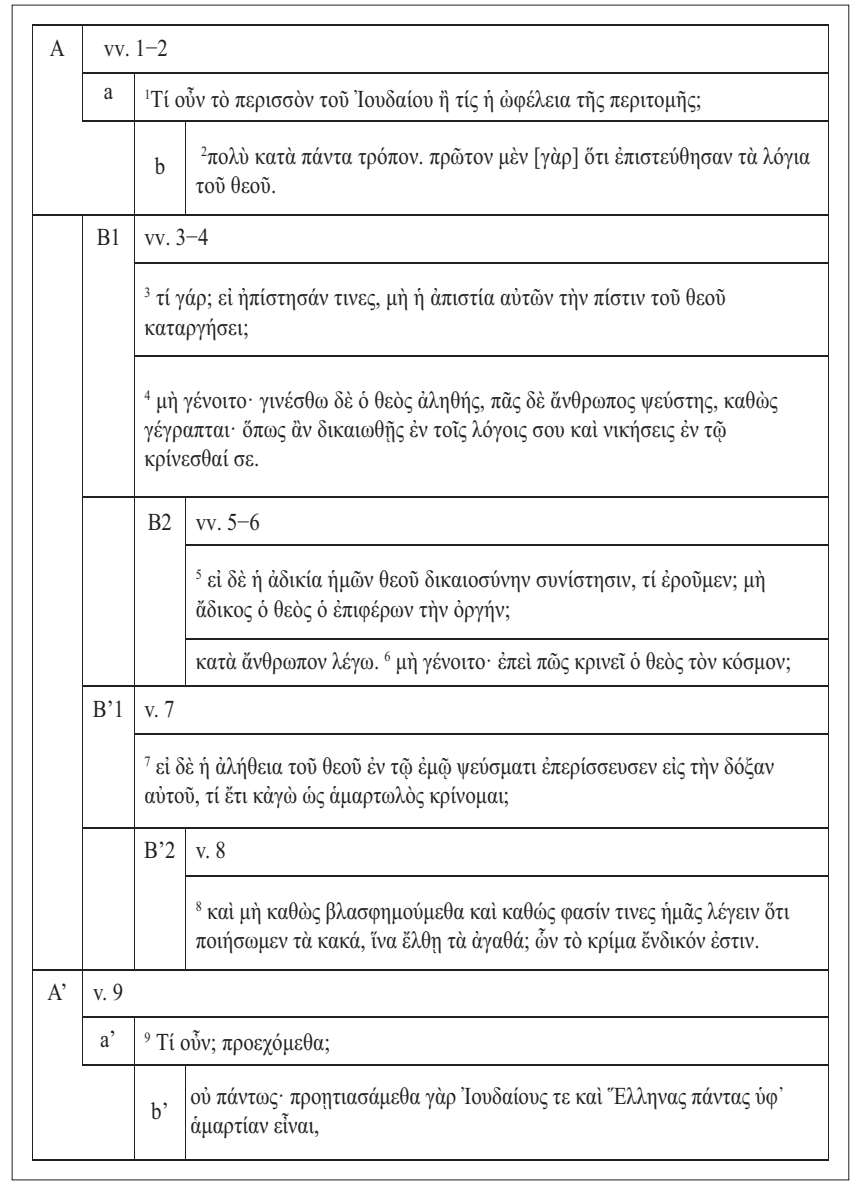

FIGURE 4: The chiastic structure of Romans 3:1-9.

ethnic Jews. That is, Romans 2:17-24 should be regarded as Paul's discussion about Jewish pride, and this theme is

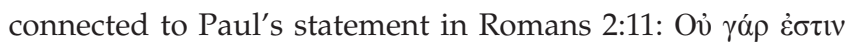

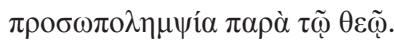

Therefore, the contrast in Romans 2:28-29 is not the antithesis between the circumcised Jews and the uncircumcised Gentiles, but between the Jews without the circumcision of the mind and the Jews whose mind was transformed according to the new covenant. So, in contrast

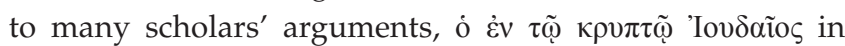
Romans 2:29 does not refer to the Gentile Christians. ${ }^{14}$ This point is connected to Romans 9:7-8: 'not all of Abraham's children are his true descendants; but "It is through Isaac that descendants shall be named after you." This means that it is not the children of the flesh who are the children of God, but the children of the promise are counted as descendants' (NRSV). Thus, Paul's statement in Romans 2:28-29 should be understood in terms of an intra-Jewish discussion, not of ascribing Jewishness to Gentile Christians.

The circumcision in Judaism can be viewed as the guarantee of salvation, ${ }^{15}$ but these verses (Rm 2:28-29) should be

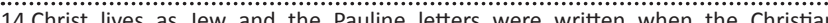
communities were parts of Judaism. Accordingly, the disputes in the Paulineletters communities were parts of Judaism. Accordingly, the disputes in the Pauline letters conflict (Campbell 2008:42).

15. For example, Jubilees 15:28-32. 
interpreted in terms of the question: 'Who is the real Jew?' This point does not deny the value of the circumcision or the circumcised Jews, but it indicates that the circumcision of the mind is needed for the Jews in order to obey the law (Rm 2:27). ${ }^{16}$ That is, the circumcised Jews also need the circumcision of their mind according to the new covenant.

Then, what is the circumcision of the mind? It should be noted that membership of the true Israel was defined in terms of the circumcision of the mind. The circumcision of the mind in Romans 2:29 is related to the concept of the hard

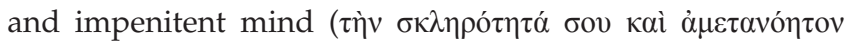
$\kappa \alpha \rho \delta i \alpha v)$ in Romans 2:5. Further, we also find the concept of the hardness of the mind relating to the state of the Jews in Romans 11:7:

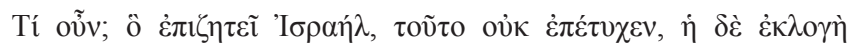

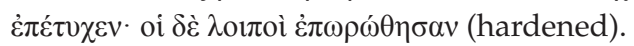

According to Romans 11:7, there are two kinds of Jews: the remnant chosen by grace ( $\mathrm{Rm} 11: 5)$ and the hardened rest (Rm 11:7). Paul's distinction of the Jews recalls Paul's division

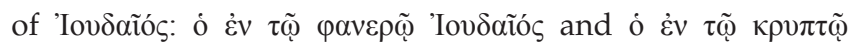

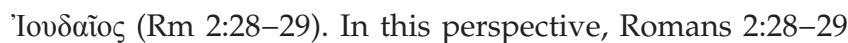
foreshadows Paul's discussion in Romans 11:1-7.

The theme of the hardness of the mind is frequently found in the Old Testament (e.g. Ex 7:3, 13, 22; 8:15; Ez 11:19; 36:26-27; Dt 29:18; Is 63:17). The pharaoh's hardness of the mind in Exodus is mentioned in Romans 9:18. In an eschatological perspective, the promise to remove the hardness of the mind

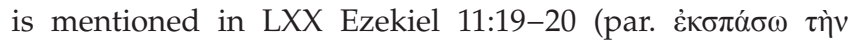

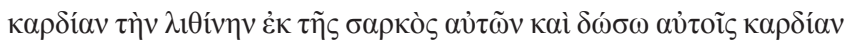

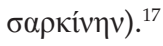

We should also note, in the following verse, the circumcision of the hardened mind: (LXX Deuteronomy 10:16) ' $\alpha \alpha i$

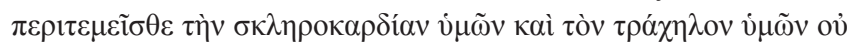

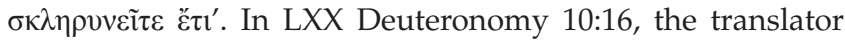
does not express the circumcision of the foreskin (תלרע), but

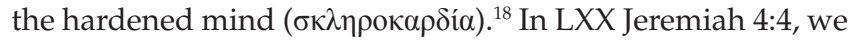

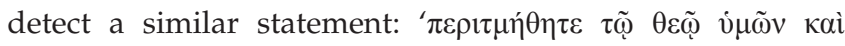

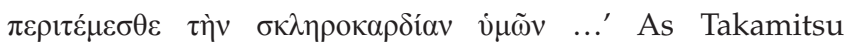
Muraoka (2010:514) argues, $\sigma \kappa \lambda \eta \rho о \kappa \alpha \rho \delta i ́ \alpha$ in the LXX is related to the disobedient mind which rejects the obedience of God's will. ${ }^{19}$ So, the theme of the circumcision of the mind was connected to the theme of obedience towards the law. It can be considered as the transformation of the mind which was expected as an eschatological event.

16.See 2 Corinthians $3: 3$, where Paul states that the Law should be written in the mind

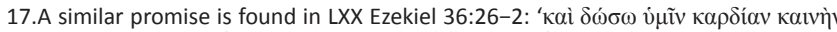

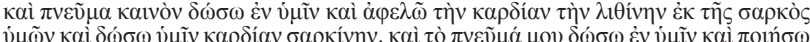

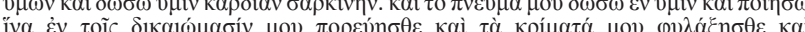

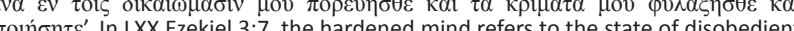
$\pi$ om $\sigma \eta \tau \varepsilon$. In LXX Ezekiel 3:7, the hardened mind refers to the state of disobedien

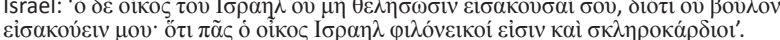

18.See also LXX Deuteronomy 30:6.

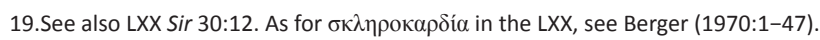

In the Dead Sea Scrolls, the removal of the hardened mind and giving the new mind are clearly referenced. In 1QS 5:5, the circumcision of the mind refers to transforming the inclination (cf. 1QS 2:11-17; see also $1 \mathrm{QH}^{\mathrm{a}} 7: 16$; CD 2:16; Wells 2014:83). The circumcision of the inclination of the mind is concerned with the transformation of the disobedient mind. In CD 1:8-10, the circumcision of the mind is fulfilled when the teacher of righteousness comes. So, in CD 1:8-10, the circumcision of the mind is an eschatological concept. ${ }^{20}$ Particularly, in CD 1:8-10, the circumcision of the mind is the special ability of the understanding of the Torah, and it was believed that the Qumran community members as the true Israel will possess the ability to understand and obey the Torah through the circumcision of the mind.

Philo of Alexandria allegorises the eschatological promise of the new mind. Yet, we are not supposed to conclude that Philo discarded the surface meaning of a text. In Philo's allegorical commentaries, the literal sense comes first, and the allegory is based on the literal meaning. For Philo, the hardness of the mind is related to the disobedience towards the Torah (De specialibus legibus 1.305-6). In particular, the circumcision of the mind is symbolically understood as the removal of the passion or desire (Legum allegoriae 3.140). The model of the hardness of the mind is Esau, Jacob's brother (De fuga et inventione 42). Esau is irrational and a slave by nature (Legum allegoriae 3.88). The epistemological quality is innately bestowed upon Isaac (De sobrietate 8-9; De sacrificiis Abelis et Caini 6; De cherubim 1-10), it is also acquired by train of thought just as Jacob (De congressueru ditionis gratia 129; De agricultura 51). In Philonic literature, the transformation of the mind is connected to the inscription of the Torah in the mind and the discernment of virtue, the capacity of the understanding and the

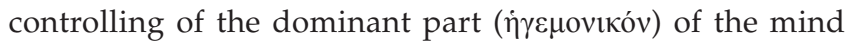
over the senses (De agricultura 83, De decalogo 142-46). The circumcision of the mind is related to Philo's epistemological theory. Thus, in these documents, the true Israel is redefined in terms of their ability of understanding obtained through the circumcision of the mind.

On the contrary, it should be noted that, as discussed above, Philo does not repudiate the literal meaning of the text, ${ }^{21}$ and the literal observance of the Jewish ritual law was significant for him. Yet, it seems that Paul accepts the allegorical meaning rather than the literal meaning of the Jewish ritual law. For Paul, while the circumcision and the Jewish ritual are beneficial and meaningful in some dimensions (Rm 3:1-2), the Jewish ritual law concerning the circumcision and the calendrical regulations does not have to be obeyed. What is important for Paul is not the literal observance (the physical circumcision) of the Jewish ritual law in a superficial aspect but the transformation of the heart (the circumcision of the

20.The ideas of the transformation of the mind are found in 4 Q. 41610,$19 ; 10 S \times 14-8$. 1OS IV 22-2; $40365104 ; 404111$ ii 9; etc.

21.For this point, see Philo's adapted 'contemporary Alexandrian Platonism'. See Dillon (1996:182) 
mind) on a deep level. ${ }^{22}$ That is, the identity of the people of God is determined not by physical circumcision but by internal circumcision. ${ }^{23}$

Paul's discussion of the circumcision in Romans 2:28-29 can also be understood in the wider Jewish context. In some Jewish literature, the circumcision of the mind is concerned with the transformation of the disobedient mind. So, we can understand Paul's discussion in Romans 2:28-29 in terms of Jewish expectation of the eschatological circumcision of the mind, and it is apparent that Paul distinguishes between two kinds of Jews: Jews without the circumcision of the mind and Jews whose minds were circumcised. In Romans 2:29, Paul's dichotomy between the Spirit and the letter

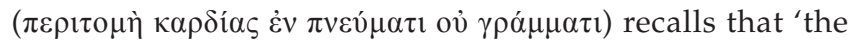
letter $(\gamma \rho \alpha \dot{\mu} \mu \alpha)$ kills, but the Spirit $(\pi v \varepsilon v \tilde{\mu} \alpha)$ gives life' in 2 Corinthians 3:6. In the context of 2 Corinthians 3, the Spirit in Corinthians 3:6 symbolises the transformation of the mind according to the Holy Spirit, and the letter signifies the mind without the internal transformation. In a similar vein, what Paul is claiming in Romans 2:28-29 seems that the surficial obedience without the transformation of the mind does not guarantee the authentic obedience at which the law aims. In this perspective, the real obedience is enabled even to the Jews through the circumcision of the mind.

In addition, redefining the true Israel and excluding some ethnic Jews from being the true members of Israel was common in ancient Jewish literature. Some Jewish communities (or sects) claimed that they are the true members of Israel, and that the priests and Jews are the false Jews who were destined to be under divine judgement. ${ }^{24}$ In this regard, it is conceivable in the ancient Jewish context that Paul redefines true Jewishness in terms of true (internal) obedience towards the Torah.

In conclusion, we have explored the structures in Romans 2:1-3:9 in order to understand the identity of the interlocutor in Romans 2:17-2:29. According to Paul's argument design in Romans 2:1-3:9 (see sections 2.1-3), 'All the people who judge' in Romans 2:1 refers to both the Jews and the Gentiles. Romans 1:18-32 is concerned with Gentile sins, and Romans 2:1-16 is related to all people including the Jews and the Gentiles who judge. Romans 2:17-29 is also concerned mainly with the Jews. The interlocutor in Romans 3:1 is

\footnotetext{
22.An allegory is delineated by Paul in Galatians 4:21-31. In the allegory of Hagar, Paul clearly distinguishes the present (earthly) Jerusalem from the heavenly world. So, in Paul's cosmic dualism, the present Jerusalem is inferior to 'the Jerusalem above' which is a part of the heavenly realm. In this allegory, the meaning of the earthly Temple is denied, and likewise, the ordinance for the physical circumcision should not be followed. Rather, the authentic temple is located in the heaven, and, in this allegory, we discover the reason the physical circumcision is not valid for Paul.

23. Daniel Boyarin discusses a significant point of Paul's allegorical re-interpretation of the Sarah and Hagar story. Boyarin's $(1994: 13,38,59)$ principal focus is placed upon Paul's Hellenistic notion of universalism, and he argues that Paul transcended 'Israel in the flesh' through his allegorical interpretation of the scripture and "srael in the flesh' through his allegorical interpretation of the scripture and even though 'it does not imply a rejection of the body'. For a critique of Boyarin's view, see Barclay (1998:536-556).

24.For example, 1Q34+1Q34bis 1-3 i 7; CD A VI 5; 1 En 38:3-4; 39:4-5; 45:4-5.
}

connected to Romans 2:17-29 with an inferential conjunction. In the conclusion ( $\operatorname{Rm~3:9),~Paul~asserts~that~Jews~and~}$ Gentiles alike are under divine judgement. So, the flow can be organised on the basis of our previous structural analysis as follows:

- Romans 2:1-16: Paul's critique towards all the people (from the Gentiles to the Jews)

- Romans 2:17-28: Paul's critique towards the disobedient Jews

- Romans 3:1-9: God and his judgement (from the Jews to the Gentiles).

Thus, in Romans 2:1-3:9, Paul discusses that Jews and Gentiles alike are under God's judgement, and in this context, it is more likely that the interlocutor in Romans 2:17-29 is Jewish, as seen above. Furthermore, the interlocutor in Romans 2:17 is not a circumcised Gentile but a Jew.

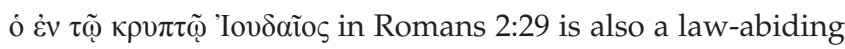
Jew whose mind was transformed, not a Gentile Christian. In this context, the identity of the interlocutor in Romans 2:17-29 can be understood as Jewish.

\section{Conclusion}

As shown above, contrary to the view of Thorsteinsson and Thiessen, it can be inferred that the identity of the interlocutor is not the Jewish proselytes, but the Jews, on the basis of our structural analysis. In Romans 2:17-29, the identity of the people of God is redefined in terms of the transformation of the mind (i.e. the circumcision of the heart), and the discussions on the historical context of the transformation of the mind also support the fact that the interlocutor in Romans 2:17-29 is Jewish.

\section{Acknowledgements Competing interests}

The authors declare that they have no financial or personal relationships that may have inappropriately influenced them in writing this article.

\section{Authors' contributions}

Both authors have equally participated in the research and the writing of this article.

\section{References}

Barclay, J.M.G., 1998, 'Paul and Philo on circumcision: Romans 2:25-9 in social and cultural context', New Testament Studies 44, 536-556. https://doi.org/10.1017/ S0028688500016714

Bassler, J., 1982, Divine impartiality: Paul and a theological axiom, Scholars, Chico, CA. Bauer, D., 1988, The structure of Matthew's gospel: A study in literary design, JSOT Press, Sheffield.

Berger, K., 1970, 'Harthezigkeit und Gottes Gesetz: Die vorgeschichte des antijüdischen Vorwurfs in Mc 10:5', Zeitschrift für die Neutestamentliche Wissenschaft 61, 1-47. https://doi.org/10.1515/zntw.1970.61.1-2.1

Boyarin, D., 1994, A radical Jew: Paul and the politics of identity, University of California Press, Berkeley, CA.

Brouwer, W., 2000, The literary development of John 13-17: A chiastic reading, Scholars, Atlanta, GA 
Campbell, D.A., 2009, The deliverance of God: An apocalyptic rereading of justification in Paul, Eerdmans, Grand Rapids, Ml.

Campbell, W.S., 2008, Paul and the creation of Christian identity, T\&T Clark, London.

Cranfield, C.E.B., 1975, A critical and exegetical commentary on the Epistle to the Romans 1-8, T\&T Clark, Edinburgh.

Dillon, J., 1996, The middle Platonists: 80 B.C. to A.D. 220, Cornell University Press, Ithaca, NY.

Dorsey, D., 1999, The literary structure of the Old Testament: A commentary on Genesis-Malachi, Baker, Grand Rapids, MI.

Dunn, J.D.G., 1988, Romans 1-8, Word, Waco, TX.

Elliott, N., 2014, The rhetoric of Romans: Argumentative constraint and strategy and Paul's debate with Judaism, Fortress, Minneapolis, MN

Kim, S.-H., 2014, Sourcebook of the structures and styles in John 1-10: The Johannine parallelisms and chiasms, Wipf and Stock, Eugene, OR.

Moo, D., 1996, The epistle to the Romans, Eerdmans, Grand Rapids, MI.

Muraoka, T., 2010, A Greek-English Lexicon of the Septuagint, Peeters, Louvain.

Nygren, A., 1967, Commentary on Romans, Westminster, Philadelphia, PA.
Stowers, S.K., 1981, The diatribe and Paul's letter to the Romans, Scholars, Chico, CA. Tobin, T. H., 2014, Paul's rhetoric in its contexts: The argument of Romans, Hendrickson, Peabody, MA.

Thiessen, M., 2014, 'Paul's argument against Gentile circumcision in Romans 2:17-29', Novum Testamentum 56, 373-391. https://doi.org/10.1163/15685365-12341488

Thomson, I.H., 1995, Chiasm in the Pauline letters, JSOT Press, Sheffield.

Thorsteinsson, R.M., 2003, Paul's interlocutor in Romans 2: Function and identity in the context of epistolography, Almqvist \& Wiksell, Stockholm.

Walsh, J.T., 2001, Style and structure in Biblical Hebrew narrative, Liturgical, Collegeville, PA.

Welch, J.W., 1981, Chiasmus in antiquity: Structures, analyses, exegesis, Gerstenberg Provo, UT.

Wells, K., 2014, Grace and agency in Paul and Second Temple Judaism: Interpreting the transformation of the heart, Brill, Leiden.

Windsor, L.J., 2014, Paul and the vocation of Israel: How Paul's Jewish identity informs his apostolic ministry, with special reference to Romans, Walter de Gruyter, Berlin.

Witherington, B.III., 2004, Paul's letter to the Romans: A socio-rhetorical commentary, Eerdmans, Grand Rapids, MI. 